\title{
Introduction
}

\section{Sporting subalternities and social justice: rethinking South African sports studies}

\author{
Tarminder Kaur \& Gerard Akindes \\ Dr T Kaur, Institute of Reconciliation and Social Justice, University of the Free State, South Africa; Email: \\ kaurt@ufs.ac.za \& Dr Akindes, Research Manager, Josoor Institute, Doha, Qatar; Email: gakindes@gmail.com
}

In asking: "How does sport help us better understand the richness and complexities of African experiences, in the past and present?', Peter Alegi (2014) sets out an agenda for a field of research, we call: Sports Africa. Over the past three decades, study of sports in African Studies has gained some recognition with its own body of knowledge and debates. This is an achievement of the pioneering sports Africanists and social historians, who wrote on a topic that was yet to be seen worthy of academic scrutiny (see for example: Baker and Mangan 1987; Mélik-Chakhnazarov 1970; Jarvie 1985; Grundlingh 1994 1995; Bale and Sang 1996; Devile-Danthu 1997; Nauright 1998; Booth 1998; Odendaal 2003; Alegi 2004, among others). This special issue is a modest contribution to the growing and rigorous scholarship that wishes to claim African Sports Studies as a serious and distinct academic field. With this in mind, we invited and solicited research papers that focus on the structures and relations of power within which sports are accessed, practiced and experienced in the everyday on this vast and diverse continent of Africa, as well as those who remain connected to Africa across the world. Therefore, Africa, as presented in this collection, is part of the world, intricately interconnected, simultaneously affecting and affected by change.

Contemporary Africa and sports are tied to the colonial past of the continent. Introduction of "modern" sport in Africa is intrinsically connected to Europe's colonial project and the agents thereof, including the army, the school system and 
the religious missions. Regardless of governing ideologies, modern sports played an important role in simultaneously separating and incorporating the colonisers and the colonised into racial, social, material and political folds. Although many sports, especially soccer, have been appropriated by throughout the time, access to organised sport and quality facilities continues to be defined by the world shaped by the colonial project (Alegi 2010). Within or outside the borders of the independent nation-states the structural legacy of colonial relations continues to define sports organisations and their relations with the global sports governing bodies and the rich elite sports systems in place in Europe or North America. The economic map of global sports still correlates with Immanuel Wallerstein's (1987) World System, with a core, a semi-periphery and a periphery. The modern world system has supported several African sports scholars' theorisation of the asymmetrical socio-economic structures and relations between Africa and Europe. ${ }^{1}$ The asymmetry reproduced within the peripheries shapes as well as is shaped by the various forms of local, regional, social and class disparities, creating various and particular forms of subalternities in the post-/neo-colonial Africa.

Sport Africa: Sporting Subalternities and Social Justice is a call for attention to the concerns of social (in)justices within the layers and multitudes of colonial configurations of sports in and of Africa, in the everyday. It invited accounts that shed light on the intermediary, peculiar and contradictory ways in which relations of power are constructed, performed, struggled over, and the social meanings these take on in the context of sports. Such a project necessarily means engaging with and deconstructing the many layers of centres and peripheries that compose sport structures, processes and experiences. The concept of subalternity, to this end, facilitates a language and a critical lens that interrupts "assumed" and "understood" meanings associated with identities such as African, black, women, underdeveloped, colonised, among others. For this issue, we also sought studies that looked beyond the two dominant frameworks, one of which focuses on elite sports, and the other on uses of sport to resolve Africa's "development" problems. In an attempt to advance and complicate understandings and debates on social, economic and political winners and losers in Sports and Africa, this introduction starts with theorising sporting subalternities, by drawing into discussion the six research papers and five book reviews.

1 The early FIFA power struggle between Europe and Africa is theorised by Paul Darby (2013, also see 1997). The Modern World System theory has been applied to the structuring forces of African football migration by Raffaele Poli (Poli 2010). 


\section{Theorising sporting subalternities}

Concepts like "nation," "society," and "culture" name bits and threaten to turn names into things. Only by understanding these names as bundles of relationships, and by placing them back into the field from which they were abstracted, can we hope to avoid misleading inferences and increase our share of understanding (Wolf 2010: 3).

This project of defining sporting subalternities and foregrounding a research agenda that engages with concerns of social justice is the one that treats both Sports and Africa as 'bundles of relationships', and not things unto themselves. Subaltern refers to a social group in a relatively powerless or disenfranchised structural status. Still, it 'is not enough to simply label a group as subaltern: subalterns engage with the world in particular ways'. ${ }^{2}$ The value of a concept like subalternity, therefore, is not in how accurately the subaltern is identified, but the relationships within which subalternities are constructed and negotiated. As such, subalterns are defined in contrast to other dominant/hegemonic group(s). A study of subalternities includes documenting, analysing and reflecting upon the interactions in which domination is resisted, reproduced or appropriated and, at times, over trivial issues in the mundaneness of the everyday, while privileging the perspectives, agency and positionalities of subalterns (Scott 2013). The intellectual project of subaltern studies ${ }^{3}$ is known for valorising, drawing on and engaging with various expressions and performances of subaltern agency, inter- as well as intra-group power relations, layers of micro-politics and defiance (Guha and Spivak 1988; Spivak 1990; Kapoor 2004). The argument we wish to carry through this issue is that the autonomous spaces of sport, enjoyment, imagination and ingenuity hold much promise in accessing complex understandings of broader social, economic and political processes (Kaur 2016).

The concept of subaltern and subalternity has been employed in many different contexts and through many different disciplinary combinations, with an

2 Robert Gordon (2017) personal communication.

3 'Subaltern studies' is an intellectual project, led by Ranajit Guha and other South Asian scholars to recover social histories of those whose lives were unintelligible in the nationalistic historical narratives that failed to deal with their internal-contradictions. Spivak's Can the Subaltern speak? - a constructive critique of 'subaltern studies' - has, arguably, been an important intervention to the studies in advancing and reshaping this intellectual project (Chatterjee 2012; Guha and Spivak 1988; Spivak 1995). More recently, Vivek Chibber (2013) points out important slippages and limitations in subaltern studies towards forms of cultural essentialism. Still, there remains useful analytical pointers within this heavily debated project of subaltern studies in uncovering the social histories of those remaining absent from textual archives or employing non-vocal expressions of agency. 
overriding intention 'to examine the complex relationship between power, culture and knowledge in a postmodern paradigm' (Bandyopadhyay 2009: 2270). Central to the intellectual project of subaltern studies was its critique of nationalism and the national postcolonial history that narrated the making of a nation only from the perspectives and political consciousness of the colonised elites. Of particular note in the shaping of this formative project of its time were the seminal contributions of Ranajit Guha $(1997 ; 1983 ; 1982)$ on 'peasant insurgency in colonial India', where he observed 'that the Indian political elite internalized and used this language of political modernity, but this democratic tendency existed alongside and interlarded with undemocratic relations of domination and subordination' (Chakrabarty 2000: 23). His attention to such a complex web of social and political relations and domains exposed 'the failure of the bourgeoisie to speak for the nation' (Chakrabarty 2000: 22) [Guha's emphasis]. It is to this end that Dipesh Chakrabarty argued: 'There was, in fact, no unitary "nation" to speak for' (2000: 22) [quotation marks in original]. The ideas, observations, critiques and concerns that emerged from subaltern studies were thus premised on the 'consideration of the autonomy of the subaltern agents and agencies' in bringing about social and political changes (Bandyopadhyay 2009: 2270). Chakrabarty explains that Guha's use of the terms 'autonomy of consciousness' or 'peasant subjecthood' to refer to 'something immanent in the very practices of peasant insurgency' and his examination of 'rebel practices [was] to decipher the particular relationships - between elites and subalterns and between subalterns themselves' (2000: 23).

From these foundations, subaltern studies have long broadened their scope of analysis to 'embodied practices as activities that people carry out for their own sake,' rather than being 'concerned with uncovering the implicit conceptual structures that supposedly underlie the practical activities of people who do not produce large bodies of texts of their own' (Chatterjee 2012: 49). While implicit in the documented anthropologies and histories of African sports (see for example: Alegi 2004; 2017; Booth 2016; Darby 2013; Desai 2016; Grundlingh 2014; Odendaal et al. 2017), by explicitly theorising sporting subalternities we hope to advance a kind of thinking and studying of African sports and sports in Africa that challenges and disrupts established understandings and boundaries of both Africa and sports. The spaces and practices of sports operate on human stuff, imbued with constructed meanings and multitudes of power relations, shaped by particular histories and politics. Similarly, grounding their work in the history, politics and concerns of social justice, the contributors to this issue pay a close attention to relationships, particularly those of power, to capture the range of unique and ingenious ways that sport forms part of African past and present. 


\section{Organisation and contributions of the Special Issue}

The six articles based on original research and the five reviews of recent sports books that make up this special issue, all, in one way or other, demonstrate and argue for the significance of subjecting sports to social-historical and anthropological analyses. By maintaining their focus on subalternity, as in attending to the complex web of power relations that shape experienced realities, authors draw out and reflect on the social injustices that take expression in and through sports. Critical treatment of textual sources and purposeful interviews inform the first three articles by Sikes, Engh and Potgieter, and Khan, while the later three articles by Roos, Truyts and Kaur situate their ethnographies in the history of racial and classed inequalities. In the paragraphs that follow, we link our theorisation of Sporting Subalternities and Social Justice to the broader themes and implicit arguments that this collection's contributors advance.

With the benefit of hindsight and a focused examination of the political contestations around South Africa's participation in the 1968 Olympics, Michelle Sikes's article shows just how messy were the processes towards promoting a just cause. Exposing the reluctance of the International Olympic Committee (IOC) to uphold its own celebrated principles of non-discrimination, as well as the cosmetic adjustments and strong lobbying by the apartheid government to participate in the Olympics, Sikes's research offers a grounded refutation to popular celebrations of the role of sports and the IOC in defeating apartheid. Attending to the geopolitics of the time, she describes the struggles and politics that led to the eventual expulsion of South Africa from the 1968 Olympics in Mexico. Despite their relatively compromised position of power and subalternity compared to politically dominant nations, the newly independent African states plied collective pressure that enabled them to use the platform of international sports to fight the good fight.

Questioning the popular claims for sport's role in promoting gender equality and women's empowerment, Mari Haugaa Engh and Cheryl Potgieter show how heteronormative ideals and racial stereotypes are imposed and reproduced in popular representations of elite sports women. Drawing on the public debates and media sources on Eudy Simelane, Caster Semenya and Portia Modise, Engh and Potgieter elaborate on how the three women athletes are annihilated or domesticated or expelled for not fitting in with socially assigned "norms". By exposing the hypocrisies and tensions of being celebrated as 'exceptional' athletes (who are only exceptional enough to remain subservient to dominant expectations of sex/gender/race), their analysis highlights the limitations and dangers in hailing sport to promote social justice. 
In an original social history exploration of mountaineering as a sport, Farieda Khan grapples with how unequal and exploitative relations between the natives and colonial settlers consolidated South Africa as a thoroughly, and legally, unjust society. Unlike Sikes's and Engh and Potgieter's papers that expose struggles in and limitations to achieving social justice in and through sports, Khan uses the sport of mountaineering as a lens to show the injustices that shape and reshape the social fabric of the Cape over a century, as race, class and politics interact. Of particular note is her documentation of how indigenous populations, subsisting through their expert knowledge of the mountain, are gradually transformed into racialised subjects of white colonial rule, with increasingly restricted access to the mountain, first as mere porters and eventually as complete outsiders, lacking knowledge, expertise and the desire for mountaineering. Khan's work exposes the generational and systematic subalternity of those racialised as black and coloured in the Cape. Inferences could be drawn from the first three papers to argue that achievement of social justice and transformation necessarily means engaging with and acknowledging localised, specific and relational histories, even of those aspects of life that might be relegated to seemingly trivial realms that fail to draw the attention they deserve.

Reflecting on the moral conundrums and responsibilities of an historian of white subalternity in South Africa, Neil Roos offers a 'gonzo-ethnography' from the stands of a Speedway (car-racing) meeting in Bloemfontein. Weaving in a personal narrative and associations to car-racing from his childhood in a working-class environment with aspirations to be otherwise, Roos situates his critique of violent enactments of whiteness within the internal frictions and historical baggage of white subalterns. Once again, Roos's paper alerts us to the damaging forms of belonging, entitlement and humiliating forms of othering that remains present in the contexts of sports. Despite the triviality and temporality of the event, and low personal or financial stakes, the shared leisure space swiftly slipped into a crime scene, implicating even the most uninvolved - the author. Roos's contribution, perhaps, deals most directly with the complexity and interlinkages of the subalternity-social justice-sports nexus.

In a richly reflective piece, Carina Truyts shows how sports studies could benefit from anthropological analysis, and conversely, how sites of sports present an ideal setting to garner ethnographic insights. Inspired by Max Gluckman's (1940) classic 'The Bridge' paper, she offers a situational analysis of two sports days: firstly, a retrospective account from her own school sports experiences and second an account from her fieldwork research in the Dwars River Valley. Embedding herself in the two situations, both as a participant and as an observer, she reflects on the colonial histories and modalities that shape these two 'sportified' and sacralised spaces. On one hand, her urban Centurion school 
sports day embraces history as an elite tradition that naturally takes its pupils to a future of excellence in every field of their lives. On the other hand, the coloured participants at the Dwars River Valley Derby day intentionally structure the event as a way to escape the stigmatised past and present, and enact respectability that, for many, remains unavailable in the everyday life of material poverty (Ross 2010). Beautifully bridging the two sports days separated by time, space, geography, race and class, Truyts's contribution demonstrates the significance of attending to relationships that give meaning to the spectrum of inequalities.

Maintaining the focus on relations, time and space, Tarminder Kaur's ethnography of sports among the farm workers of the Cape Winelands works with the tensions in contrasting meanings, desires and experiences that sports stirs in the contexts of "development" (Ferguson 1990). By examining sports as an aspect of farm worker development and by extension, an aspect in achieving ethical wine production, Kaur expounds on the contradictions that discourses of 'sports-for-development' absorb. This ironic question of how sport makes wine production "fair" draws attention to the history of slavery and exploitative labour practices that continue to tarnish the reputation of the South African wine industry. She argues that it is ultimately the condition of subalternity of the farm workers - those who continue to need development rather than just wages and fair treatment - that is affirmed in the community development projects of Fairtrade (the selected case study). The ethnographic detail and context within which various claims to sport were made illustrate a range of agendas including the ways in which sports get mobilised and appropriated to express deep-held desires for a better life, and the (oftentimes ironic) multi-directionality of power relations that support and undermine these projects all at the same time.

Each contribution highlights struggles for social justice that remain to be worked out, better understood and fought for, in and through sports. Of course, social justice is also not a 'thing', but an action that relies on the 'bundles of relationships' of power that are often unbalanced, favouring particular group(s) over the other(s). These six articles exemplify and support the kind of research and social justice action we hope to promote in theorising sporting subalternities. Our research agenda, not so novel at its core, is also reflected in the recent monographs for which we solicited reviews to be included in this special issue. These reviews encompass somewhat broader regional diversity with books on Mozambican football (Domingos 2017); migration of African soccer players across the Portuguese colonial empire (Cleveland 2017); an autobiographical account of a West African professional footballer (Obilalé 2015); and two books on the untold stories and struggles of black South African cricketers (Desai 2016; Odendaal et al. 2017). These publications mark an important juncture in the sports history of Africa, and we hope the reviews published here will inspire students of sports and 
Africa to read the full texts and propel researchers in the directions set out by this collection for future research in the field of Sports Africa.

\section{Concluding remarks}

Recognising the significance of social sports to African studies, William Baker and James Mangan (1987) edited what could be considered among the founding collections of essays in the social history of sports in Africa. In the introduction, they justified their decision to exclude essays on South Africa and apartheid sports, arguing that the issue was well covered in the existing literature at the time (1987: ix). While we are indebted to Baker and Williams, and many other historians of sports and Africa, for promoting African sports studies to this stage where it is not as readily dismissed as it once was, this special issue has remained South Africa-focused. All the articles that were eventually accepted for publication focus on South Africa, and interrogate the legacies of apartheid in the way sports are structured and experienced in the everyday. We are grateful to all the authors and book reviewers who contributed to this special issue, and hope that this issue will inspire scholarship on sports from across the vast continent of Africa north of the Limpopo River. Sports Africa as a field of research remains rich in promise, with many more social histories and ethnographies to be recorded, analysed and reflected upon. It is in this promise that we find consolation for the content that has remained largely from the Anglophone world of South Africa. We hope future studies and collections will draw in conversations from the diversity of Francophone and Lusophone Africa as well as all the many media through which Africa and Africans make sense of their sporting worlds. We hope the modest contribution that this special issue makes to the growing body of knowledge in sports studies contributes to 'better understand the richness and complexities of [South] African experiences, in the past and present' (Alegi 2014). Ultimately, this is an invitation to draw sports Africanists into conversation, critiquing, amending and extending the debates we and contributing authors have presented here.

\section{Acknowledgment}

This special issue, a milestone of the Sports Africa conference, was made possible with the support of the Institute for Reconciliation and Social Justice at the University of the Free State in Bloemfontein, South Africa, under the leadership of Andre Keet and JC van Der Merwe.

We thank all the anonymous reviewers who gave their valuable time to provide thoughtful comments and feedback, from which both authors and guest editors benefited, and which made an important contribution to the quality of 
the publication. We are also immensely grateful to all the authors featured in this special issue, and for their patient work with the editors and reviewers.

We, as guest editors, are grateful to Rene Eloff, the assistant editor of ACTA Academica for his consistent, critical and encouraging support, guidance and understanding throughout this unexpectedly long process of putting together this Special Issue. Without your enthusiastic and patient approach, this project would not have been the same. Thank you.

We express our appreciation to Peter Alegi and Martha Saavedra for having been among the most consistent champions and contributors to the conference since its inception in 2004. We would like to extend our gratitude to Ohio University for having been the institution that carried the initial conferences and contributed to enriching the traditional academic space with Africa Sports. We are also grateful to all the contributors, presenters, UFS volunteers and faculty for their support and participation.

\section{Bibliography}

ALEGI P (2014) Sports in Africa group: ten years on. YouTube. [Available online: https://www.youtube.com/watch? v=ekcdt36TLUE]

ALEGIP (2010) African soccerscapes: how a continent changed the world's game. London: Hurst \& Co. https://doi.org/10.1353/book.598

AlegI P (2004) Laduma! soccer, politics and society in South Africa. Scottsville: University of KwaZulu-Natal Press.

ALEGI P (2017) Black sports matters: sporting subalterns' quest for social justice in African history. Keynote address presented at the Sports Africa Conference, sporting subalternities and social justice, held at the University of the Free State, Bloemfontein, 10-12 April 2017.

BAKER WJ, MANGAN JA (1987) Sport in Africa: essays in social history. New York: Africana Pub. Co.

BALE J, SANG J (1996) Kenyan running: movement culture, geography and global change. London: Frank Cass.

BANDYOPADHYAYK (2009) Review essay: James Mills (ed), Subaltern sports: politics and sport in South Asia. International Journal of History of Sport 26(15): 2270 2283. https://doi.org/10.1080/09523360903367719

Воотн D (2016) Disentangling race: re-narrating apartheid sport? International Journal of History of Sport 33(15): 1866-1883. https://doi.org/10.1080/095 23367.2017.1319359

Воотн D (1998) The race game: Sport and politics in South Africa. London and Portland, OR: Frank Cass. 
ChAKRABARTY D (2000) Subaltern studies and postcolonial historiography. Nepantla: Views from South 1(1): 9-32.

ChatterJee P (2012) After subaltern studies. Economic \& Political Weekly 47(35): 44-49.

CHIBBER V (2013) Postcolonial theory and the specter of capital. New York: Verso.

CLEVELAND T (2017) Following the ball: the migration of African soccer players across the Portuguese colonial empire 1949-1975. Athens: Ohio University Press.

DARBY P (2013) Africa, football and FIFA: politics, colonialism and resistance. London: Routledge. https://doi.org/10.4324/9781315039527

DARBY P (1997) Theorising world football politics: FIFA, dependency and world system theory. Scottish Centre Research Papers in Sport, Leisure and Society 2(1): $36-61$.

DESAI A (2016) Reverse sweep: a story of South African cricket since apartheid. Auckland Park: Jacana Media.

DeVILE-DANTHu B (1997) Le sport en noir et blanc: Du sport colonial au sport Africain dans les anciens territoires Francais d'Afrique occidentale (19201965). Paris: L'Harmattan.

DomINGOS N (2017) Football and colonialism: body and popular culture in urban Mozambique. Athens: Ohio University Press.

FERguson J (1990) The anti-politics machine: "development," depoliticization, and bureaucratic power in Lesotho. Minneapolis: University of Minnesota Press.

GLUCKMAN M (1940) Analysis of a social situation in modern Zululand. Bantu Studies 14(1): 1-30. https://doi.org/10.1080/02561751.1940.9676107

GRUNDLINGH A (2014) Potent pastimes: sport and leisure practices in modern Afrikaner history. Pretoria: Protea Boekhuis.

GRUNDLINGH A (1994) Playing for power? Rugby, Afrikaner nationalism and masculinity in South Africa, c. 1900-70. International Journal of History of Sport 11(3): 408-430. https://doi.org/10.1080/09523369408713871

GRUNDLINGH AM (1995) Beyond the tryline: rugby and South African society. Johannesburg: Raven Press.

GUHA R (1997) Dominance without Hegemony: History and Power in Colonial India. Cambridge, MA: Harvard University Press.

GUHA R (1983) Elementary aspects of peasant insurgency in colonial India. Delhi: Oxford University Press.

GUHA R(ed) (1982) Subaltern studies I: writings on South Asian history and society. Delhi: Oxford University Press.

GuHA R, SPIVAK GC (1988) Selected subaltern studies. New York: Oxford University Press. 
JARVIE G (1985) Class, race, and sport in South Africa's political economy. London and Boston: Routledge \& Kegan Paul.

KAPOOR I (2004) Hyper-self-reflexive development? Spivak on representing the Third World 'Other.' Third World Quarterly 25(4): 627-647. https://doi.org/10. 1080/01436590410001678898

KAUR T (2016) Sporting lives and "development" agendas: a critical analysis of sport and "development" nexus in the context of farm workers of the Western Cape. PhD thesis. Bellville: University of the Western Cape.

MÉLIK-ChAKHNAZAROV A (1970) Le sport en Afrique. Paris: Présence africaine.

NAURIGHT J (1998) Sport, cultures, and identities in South Africa. London: Leicester University Press.

OBILALÉ K (2015) Un destin foudroyé: Un footballeur dans l'enfer du terrorisme. Talent Sport.

OdendAaL A (2003) The story of an African game. Claremont: David Philip.

Odendaal A, Merrett C, Winch J and Reddy K (2017) Cricket and conquest: the history of South African cricket Retold 1795-1914. Cape Town: HSRC Press.

POLI R (2010) Understanding globalization through football: the new international division of labour, migratory channels and transnational trade circuits. International Review of Sociology of Sport 45(4): 491-506. https://doi. org/10.1177/1012690210370640

Ross F (2010) Raw life, new hope: decency, housing and everyday life in a postapartheid community. Cape Town: UCT Press.

SCOTT JC (2013) Decoding subaltern politics: ideology, disguise, and resistance in agrarian politics, Asia's transformations. New York, NY: Routledge.

SPIVAK GC (1995) Can the subaltern speak? In: Ashcroft B, Grifiths B, and Tiffin H (eds) The postcolonial studies reader. New York, NY: Routledge.

SPIVAK GC (1990) Gayatri Spivak on the politics of the subaltern, interview by Howard Winant. Socialist Review 20(3): 81-97.

WALLERSTEIN I (1987). World-systems analysis. Durham, NC: Duke University Press. WOLF ER (2010) Europe and the people without history, 3rd ed. Berkeley, CA: University of California Press. 